\title{
PENGARUH KEPUASAN KERJA DAN KOMITMEN PEGAWAI TERHADAP ORGANIZATIONAL CITIZENSHIP BEHAVIOR (OCB) PADA PEGAWAI STRUKTURAL IAIN PADANGSIDIMPUAN
}

\author{
ASWADI LUBIS \\ (Dosen Fakultas Ekonomi dan Bisnis Islam IAIN Padangsidimpuan) \\ email: aswadi64@gmail.com
}

\begin{abstract}
Good behaviour is needed to support the organization, it is as the based problem in this research. The employees not only should have good skills but also good behaviours, known as extra skills. In order to know further about it, the researcher examined the effect of job satisfaction and employee commitment on Organizational Citizenship Behavior (OCB). The samples were all employees of the structural IAIN Padangsidimpuan that civil servants who numbered 53 employees. Data collection techniques used to obtain data on job satisfaction, employee commitment and Organizational Citizenship Behavior (OCB) is a questionnaire. While testing the hypothesis used multiple regression analyzes with SPSS 22. The results showed that job satisfaction to the employees of the State Islamic Institute Padangsidimpuan have a significant influence on Citizenshif Organizational Behavior (OCB) based on employee perceptions. From the analysis, the result that job satisfaction and Organizational Commitment to give effect to Citizenshif Organizational Behavior (OCB) in institutions. Job Satisfaction and Organizational Commitment influence simultaneously against Citizenshif Organizational Behavior (OCB). This is evidenced by the simultaneous test (F test) and test the coefficient of determination that is equal to $83 \%$ Citizenshif Organizational Behavior (OCB) is influenced by variations in two variables used in the study, the rest is another factor. Job satisfaction is more dominant influence on Citizenshif Organizational Behavior (OCB). This is evidenced by the regression coefficient greater job satisfaction than organizational commitment based on the study the researchers did on the institution Padangsidimpuan State Islamic Institute.
\end{abstract}

Keywords: Job Satisfaction, Employee Commitment, and Citizenshif Organizational Behavior (OCB)

\section{Abstrak}

Perlunya perilaku yang baik dalam mendukung jalannya sebuah organisasi atau lembaga menjadi dasar utama penelitian ini. Pegawai 
86 | TAZKIR: Jurnal Penelitian Ilmu-ilmu Sosial dan Keislaman

Vol. 03 No. 1 Juni 2017

tidak hanya harus memiliki keterampilan dan kualitas yang baik tetapi memiliki juga perilaku ekstra dimana salah satunya adalah Organizational Citizenship Behavior (OCB). Namun kenyataannya perilaku tersebut belum dimiliki oleh setiap pegawai. Penelitian ini melihat pengaruh kepuasan kerja dan komitmen pegawai terhadap Sikap dalam berorganisasi. Sampel dalam penelitian ini adalah 53 orang Pegawai struktural IAIN Padangsidimpuan. Data diperoleh melalui angket untuk kemudian dianalisis melalui analisis regresi dengan menggunakan SPSS. Hasil penelitian menunjukkan bahwa kepuasan kerja dan komitmen berorganisasi pegawai IAIN Padangsidimpuan masing-masing memiliki pengaruh yang signifikan terhadap OCB. Begitu pula keduanya, kepuasan kerja dan komitmen berorganisasi juga memiliki pengaruh signifikan secara bersama-sama terhadap OCB, dibuktikan dengan uji $F$ yang menunjukkan bahwa 83\% OCB dipengaruhi oleh kedua faktor tersebut. Namun kepuasan kerja lebih dominan pengaruhnya dari pada komitmen berorganisasi. Hal ini diketahui dari nilai regresi yang diperoleh peneliti lebih tinggi pada kepuasan kerja daripada komitmen berorganisasi.

Kata Kunci: kepuasan kerja, komitmen organisasi, dan OCB.

\section{PENDAHULUAN}

Kriteria kinerja yang baik menuntut pegawai untuk berperilaku sesuai harapan organisasi. Perilaku ini tidak hanya mencakup in-role yaitu bekerja sesuai dengan standar job description saja namun juga extra-role yaitu memberikan perusahaan lebih dari pada yang diharapkan. Perilaku ini cenderung melihat pegawai sebagai makhluk sosial yang memiliki kemampuan untuk berempati kepada orang lain dan lingkungannya dan juga menyelelaraskan nilai-nilai yang dimiliki dengan nilai-nilai lingkungan sekitarnya. ${ }^{1}$

Di dalam suatu perusahaan, salah satu faktor penentu dalam kepuasan dan komitmen kerja pegawai adalah turnover, hal ini besar pengaruhnya bagi kelangsungan dan kemajuan perusahaan. Sebuah perusahaan dengan tingkat turnover yang tinggi memiliki tantangan khusus bagi pengembangan sumber daya manusia karena kejadian-kejadian tersebut tidak dapat diperkirakan. Kegiatankegiatan pengembangan harus mempersiapkan setiap saat pengganti pegawai yang keluar. Ada kalanya pergantian pegawai memiliki dampak positif. Namun sebagian besar pergantian pegawai membawa pengaruh yang kurang baik terhadap

1 Sloat, K. C. M. (1999). Organizational Citizenship: Does Your Firm Inspire to be "good citizenship?". Professional Safety, Vol.44: 20-23. 
organisasi, baik dari segi biaya maupun dari segi hilangnya waktu untuk melatih pegawai pengganti dan kesempatan untuk memanfaatkan peluang².

Organizational Citizenship Behavior (OCB) berkaitan dengan manifestasi seseorang (pegawai) sebagai mahluk sosial. Dengan kemampuan berempati pegawai bisa memahami orang lain dan lingkungannya serta bisa menyelaraskan nilai-nilai individual yang dianutnya dengan nilai-nilai yang dianut lingkungannya, sehingga muncul perilaku good citizen. Kecakapan emosi (kemampuan kerja) merupakan bagian dari OCB yang dapat menghasilkan kinerja yang menonjol dalam pekerjaan.

Kepuasan kerja adalah bentuk perasaan dan ekspresi seseorang ketika dia mampu/tidak mampu memenuhi harapan dari proses kerja dan kinerjanya. Timbul dari proses transformasi emosi dan pikiran dirinya yang melahirkan sikap atau nilai terhadap sesuatu yang dikerjakan dan diperolehnya. Coba saja kita lihat di dalam lingkungan kerja. Bisa jadi ditemukan beragam ekspresi pegawai. Ada yang murah senyum dan tertawa, ada yang suka mengeluh, ada yang akrab dengan sesama mitra kerja, ada yang senang mengisolasi diri. Salah satu faktor penyebab semua itu adalah perbedaan derajat kepuasan kerja. Semakin tinggi derajat kepuasan kerja semakin bersahabat seorang pegawai dengan lingkungan kerja. Selain kepuasan kerja ada hal lain yang menjadi perilaku pegawai yang berdampak positif bagi perusahaan yaitu komitmen.

Komitmen adalah kemampuan dan kemauan untuk menyelaraskan perilakupribadi dengan kebutuhan, perioritas dan tujuan organisasi. Hal ini mencakup cara-cara mengembangkan tujuan atau memenuhi kebutuhan organisasi yang intinya mendahulukan misi organisasi dari pada kepentingan pribadi. Definisi komitmen organisasional ini menarik, dikarenakan yang dilihat adalah sebuah keadaan psikologi karyawan untuk tetap bertahan dalam organisasi. Beberapa organisasi memasukkan unsur komitmen sebagai salah satu syarat untuk memegang suatu jabatan atau posisi tertentu dalam kualifikasi lowongan pekerjaan.

Organizational Citizenship Behavior (OCB) ini memang belum begitu dikenal, namun pada dasarnya pegawai dalam suatu perusahaan atau organisasi kadangkadang sudah menerapkan Organizational Citizenship Behavior (OCB) dalam bekerja. Salah satu sikap strategik dalam divisi sumber daya manusia adalah mengembangkan Organizational Citizenship Behavior (OCB) dalam organisasi.

2 Nanggoy, S. \& Harianti, R. (2005). "Pengaruh Kepuasan Kerja Karyawan Terhadap Turnover Intentions di PT. Andalan Pacific Samudera di Surabaya" (Skripsi No.05011881/MAN/2005). Retrieved April 30, 2015. From source: http://dewey.petra.ac.id/dgt_res_detail.php?knokat=2626 
88 | TAZKIR: Jurnal Penelitian Ilmu-ilmu Sosial dan Keislaman

Vol.03 No. 1 Juni 2017

Organizational Citizenship Behavior (OCB) ini tercermin melalui perilaku suka menolong orang lain, menjadi volunteer untuk tugas-tugas ekstra, patuh terhadap aturan-aturan dan prosedur-prosedur di tempat kerja. Perilaku ini menggambarkan nilai tambah pegawai yang merupakan salah satu bentuk perilaku prososial, yaitu perilaku sosial yang positif, konstruktif dan membantu.

Organ mendefinisikan OCB sebagai perilaku individual yang bersifat bebas (discretionary), yang tidak secara langsung dan eksplisit mendapat penghargaan dari sistem imbalan formal, dan yang secara keseluruhan mendorong keefektifan fungsifungsi organisasi. Bersifat bebas dan sukarela, karena perilaku tersebut tidak tercantum dalam deskripsi jabatan, yang secara jelas dituntut berdasarkan kontrak dengan organisasi; melainkan sebagai pilihan personal ${ }^{3}$.

Robbins menyatakan kepuasan kerja mendorong munculnya OCB karena karyawan yang puas memiliki kemungkinan yang lebih besar untuk berbicara positif tentang organisasi, membantu individu lain, dan melakukan kinerja yang melampaui perkiraan normal. Karyawan yang puas mungkin lebih patuh pada panggilan tugas karena ingin mengulang pengalaman-pengalaman positif yang pernah dirasakan*.

Spector dalam jurnal Nasir mendefinisikan Organizational Citizenship Behavior (OCB) sebagai perilaku di luar persyaratan formal pekerjaan yang memberikan keuntungan bagi organisasi. Karyawan yang menunjukkan perilaku tersebut memberi kontribusi positif terhadap organisasi melalui perilaku di luar uraian tugas, di samping karyawan tetap melaksanakan tanggung jawab sesuai pekerjaannya ${ }^{5}$.

Kunci sukses pertumbuhan setiap organisasi adalah kemampuannya dalam merekrut, mengembangkan dan mempertahankan talenta sumber daya manusianya. Institut Agama Islam Negeri Padangsidimpuan telah menetapkan sasarannya untuk menjadi organisasi pilihan untuk berkarya dengan menjadi organisasi yang menawarkan lingkungan kerja positif di mana setiap individu dapat mengembangkan seluruh potensinya. Institut Agama Islam Negeri Padangsidimpuan melaksanakan struktur organisasi yang memungkinkan sumber daya manusia berkualitas dan kompetitif sehingga mampu beradaptasi dengan

\footnotetext{
${ }^{3}$ Organ, D.W. 1988. Organizational Citizenship Behavior: The Good Soldier Syndrome. Lexinton book. Lexington,MA

${ }^{4}$ Robbins dan Judge. 2008.Perilaku Organisasi.Jakarta: Salemba Empat, hal. 15

${ }^{5}$ Nasir, Mohammadi, Shahrazad, Fatimah, Khairudin, and Halim.2011. Relationship Between Organizational Citizenship Behavior and Task Performance. Jurnal ilmu Pendidikan, (Online), Vol 6, No 4
} 
kemajuan dan perkembangan ilmu dan teknologi untuk menghasilkan kerja dan pelayanan terbaik sesuai dengan yang diharapkan.

Institut Agama Islam Negeri Padangsidimpuan merupakan salah satunya Perguruan Tinggi Negeri dibawah naungan Kementerian Agama di Daerah Tabagsel yang bergerak dibidang pendidikan. Didalam mencapai visi dan misi IAIN Padangsidimpuan dibutuhkan pegawai yang berkualitas adalah yang bekerja sesuai dengan standar-standar yang ditentukan oleh kementerian dan lembaga untuk mampu menghasilkan kerja sesuai bahkan lebih dari apa yang diharapkan oleh lembaga.

Jadi diharapkan pegawai tidak hanya memiliki skill dan kualitas yang baik tetapi memiliki perilaku ekstra dimana salah satunya adalah Organizational Citizenship Behavior (OCB). Perilaku ektra tersebut seperti membantu rekan kerja menyelesaikan tugas, kesungguhan dalam mengikuti rapat-rapat organisasi, sedikit mengeluh banyak bekerja, dan lain-lain. Perilaku-perilaku ini disebut sebagai perilaku extra-role. Apalagi pada saat pimpinan melakukan evaluasi kinerja pada pegawainya, yang dievaluasi bukan hanya perilaku intra-role tetapi perilaku extra-role menjadi bagian dari evaluasi tersebut, karena perilaku extra-role memiliki kontribusi yang sama penting dengan perilaku intra-role.

Hal ini sesuai dengan Sabda Rasulullah SAW, "Sesungguhnya, di antara perbuatan dosa, ada yang tidak dapat dihapus oleh (pahala) shalat, sedekah, atau pun haji. Namun hanya dapat ditebus dengan kesungguhan dalam mencari nafkah penghidupan." (HR. Tabrani)

Dari hadits tersebut, jelaslah betapa tingginya kedudukan bekerja dalam Islam. Islam mengajarkan bahwa dalam hidup ini sudah seharusnya kita bekerja keras. Allah sangat menghargai orang-orang yang bekerja keras dalam hidupnya. Sehingga hanya dengan bekerja yang sungguh-sungguh dosa dapat dihapuskan oleh Allah Swt.

Dalam sebuah hadits Rasulullah Saw bersabda, "Barang siapa pada malam hari merasakan kelelahan karena bekerja pada siang hari, maka pada malam itu ia diampuni Allah." (HR. Ahmad). Selanjutnya, "Barang siapa yang di waktu sorenya merasakan kelelahan karena bekerja, berkarya dengan tangannya, maka di waktu sore itu pulalah terampuni dosanya."

Namun kenyataannya perilaku tersebut tidak dimiliki oleh setiap pegawai. Oleh karena itu, perilaku extra-role ini sangat didukung oleh kontribusi dari lembaga. Untuk memunculkan Organizational Citizenship Behavior (OCB) pada pegawai tentunya pegawai harus merasa puas terlebih dahulu. Aspek-aspek 
90 | TAZKIR: Jurnal Penelitian Ilmu-ilmu Sosial dan Keislaman

Vol.03 No. 1 Juni 2017

kepuasan kerja yaitu pekerjaan itu sendiri, gaji, pengakuan, supervisi, kerja sama yang baik dengan rekan kerja, serta kesempatan untuk berkembang ${ }^{6}$. Apabila karyawan sudah merasa senang, puas, dan nyaman dalam bekerja. Maka akan memuculkan perilaku Organizational Citizenship Behavior (OCB).

Berdasarkan uraian latarbelakang masalah diatas, maka penulis merumuskan tujuan penelitian, yakni untuk: a. Mengetahui bagaimana pengaruh kepuasan kerja pegawai terhadap Organizational Citizenship Behavior (OCB) Pada Pegawai Struktural IAIN Padangsidimpuan; b. Mengetahui bagaimana pengaruh komitmen kerja pegawai terhadap Organizational Citizenship Behavior (OCB) Pada Pegawai Struktural IAIN Padangsidimpuan.

\section{LANDASAN TEORI}

\section{Organization Citizhenship Behavior}

Konsep OCB pertama kali didiskusikan dalam literatur penelitian organisasional pada awal 1980an (Bateman dan Organ, 1983; Smith et al., 1983; dalam Bienstock et al., Robbins mengemukakan bahwa OCB merupakan perilaku pilihan yang tidak menjadi bagian dari kewajiban kerja formal seorang karyawan, namun mendukung berfungsinya organisasi tersebut secara efektif ${ }^{7}$. Menurut Organ, OCB adalah perilaku individu yang bebas, tidak secara langsung atau eksplisit diakui dalam sistem pemberian penghargaan dan dalam mempromosikan fungsi efektif organisasi. Atau dengan kata lain, OCB adalah perilaku karyawan yang melebihi peran yang diwajibkan, yang tidak secara langsung atau eksplisit diakui oleh sistem reward formal.

Organizational citizenship behavior (OCB) merupakan perilaku individu yang ekstra, yang tidak secara langsung atau eksplisit dapat dikenali dalam suatu sistem kerja yang formal, dan yang secara agregat mampu meningkatkan efektivitas fungsi organisasi. Organisasi pada umumnya percaya bahwa untuk mencapai keunggulan harus mengusahakan kinerja individual yang setinggi-tingginya, karena pada dasarnya kinerja individual mempengaruhi kinerja tim atau kelompok kerja dan pada akhirnya mempengaruhi kinerja organisasi secara keseluruhan.

Kinerja yang baik menuntut perilaku sesuai dengan yang diharapkan oleh organisasi. Perilaku yang menjadi tuntutan organisasi saat ini adalah tidak hanya perilaku in-role, tetapi juga perilaku extra-role. Perilaku extra-role ini disebut juga

${ }^{6}$ Sopiah.2008.Perilaku Organisasional. Yogyakarta: C.V Andi Offset, hal. 42

${ }^{7}$ Bienstock, C.C., DeMoranville, C.W., dan Smith, R.K. ( 2003). "Organizational Citizenship Behavior and Service Quality". Journal of Services Marketing, Vol 17 No. 4, 2003 pp. 357- 378 
dengan Organizational Citizenship Behavior (OCB). Organizational Citizenship Behavior (OCB) merupakan istilah yang digunakan untuk mengidentifikasikan perilaku guru sehingga dia dapat disebut sebagai anggota yang baik. Perilaku ini cenderung melihat seseorang (pegawai) sebagai makhluk sosial (menjadi anggota organisasi), dibandingkan sebagai makhluk individual yang mementingkan diri sendiri ${ }^{8}$

Sebagai makhluk sosial, manusia mempunyai kemampuan untuk memiliki empati kepada orang lain dan lingkungannya dan menyelaraskan nilai-nilai yang dianutnya. Dengan nilai-nilai yang dimiliki lingkungannya untuk menjaga dan meningkatkan interaksi sosial yang lebih baik. Terlebih lagi, untuk melakukan segala sesuatu yang baik manusia tidak selalu digerakkan oleh hal-hal yang menguntungkan dirinya, misalnya seseorang mau membantu orang lain jika ada imbalan tertentu.Organizational Citizenship Behavior (OCB) memberikan kontribusi terhadap kesejahteraan komunitasnya, transformasi sumber daya, keinovasian dan keadaptasian (Organ, 1988) serta kinerja organisasi secara keseluruhan (Netemeyer, dkk., 1997) termasuk meningkatkan efektivitas dan efisiensi pengerahan sumber daya langka, waktu dan pemecahan masalah di antara unit-unit kerja dengan cara kolektif dan interdependensi.

Kemudian juga akan mempengaruhi keputusan kompensasi, promosi dan pelatihan serta memiliki efek yang penting terhadap kinerja keuangan (MacKenzie, dkk., 1998; Motowidlo dan Van Scotter, 1994). Selain itu OCB akan menerangkan proporsi halo effect dalam penilaian kinerja (Organ, 1988) dan merupakan determinan bagi program manajemen sumber daya manusia dalam mengawasi, memelihara, dan meningkatkan sikap kerja (Organ dan Ryan, 1995) yang akumulasinya akan berpengaruh pada kesehatan psikologi, produktivitas dan daya pikir pekerja.

Perilaku tersebut tidak akan mendapat imbalan langsung atau sanksi baik dilakukan atau tidak, namun sikap konstruktif yang ditunjukkan karyawan melalui Organizational Citizenship Behavior (OCB) akan memberikan penilaian positif atasan seperti penugasan dan promosi (Bateman dan Organ, 1983). Eisenberger (1990) mengungkapkan bahwa perilaku ini berkembang sejalan dengan seberapa besar perhatian organisasi pada tingkat kesejahteraan guru dan penghargaan organisasi terhadap kontribusi mereka. Persepsi guru yang baik terhadap dukungan organisasional (Perceived Organizational Support/POS) kepada kualitas kehidupan kerja mereka akan menimbulkan rasa "hutang budi" dalam diri mereka pada

${ }^{8}$ Ariani, D.W. (2008). Perilaku Kewargaan Organisasional. http://www.ugm.ac.id /index.php? page=rilis\&artikel=1112. Diakses tanggal 15 Januari 2016. 
92 | TAZKIR: Jurnal Penelitian Ilmu-ilmu Sosial dan Keislaman

Vol. 03 No. 1 Juni 2017

organisasi sehingga mereka akan merasa memiliki kewajiban untuk membayarnya. Kualitas interaksi atasan-bawahan juga diyakini sebagai prediktor organizational citizenship behavior (OCB). Miner (1988) mengemukakan bahwa interaksi atasanbawahan yang berkualitas tinggi akan memberikan dampak seperti meningkatnya kepuasan kerja, produktifitas, dan kinerja guru. Riggio menyatakan bahwa apabila interaksi atasan-bawahan berkualitas tinggi maka seorang atasan akan berpandangan positif terhadap bawahannya sehingga bawahannya akan merasakan bahwa atasannya banyak memberikan dukungan dan motivasi.

\section{Dimensi-Dimensi Organization Citizenship Behavior}

Dua dimensi organizational citizenship behavior (OCB) yang penting menurut Williams dan Anderson (1991) dikenal sebagai OCB-Individual (OCBI, altruism, mendahulukan kepentingan orang lain) yang segera memberikan manfaat khusus individual dan secara tidak langsung melalui kontribusi terhadap organisasi (misalnya membantu rekan yang tidak masuk bekerja, memberikan perhatian secara pribadi kepada pekerja lain) dan OCB-Organizational (OCBO, compliance, kerelaan) yang memberikan manfaat terhadap organisasi secara umum (misalnya memberikan nasihat kepada karyawan yang mangkir bekerja) ${ }^{9}$.

Dimensi yang paling sering digunakan untuk mengonseptualisasi Organizational Citizenship Behavior (OCB) adalah dimensi-dimensi yang dikembangkan oleh Organ (1988). Menurut Podsakoff studi dari Katz pada tahun 1964 tentang perilaku inovatif dan spontanitas mempengaruhi penelitian-penelitian Organizational Citizenship Behavior (OCB) saat ini sehingga dimensi-dimensi dari Organizational Citizenship Behavior (OCB) terkait dengan dimensi dari studi yang dilakukan oleh Katz. Katz menyebutkan ada lima dimensi, yaitu: Cooperating with others, Protecting the organization, Volunteering constructive ideas, Self-training, dan Maintaining a favorable attitude toward the company.

Podsakoff ada tujuh jenis atau dimensi Organizational Citizenship Behavior (OCB) yang pernah digunakan oleh para peneliti. Ketujuh dimensi tersebut meliputi:

1) Perilaku menolong (helping behavior), merupakan bentuk perilaku sukarela individu untuk menolong individu lain atau mencegah terjadinya permasalahan yang terkait dengan pekerjaan (workrelated problem). Organ (1983) membagi dimensi ini dalam dua kategori yaitu altruism dan courtesy,

${ }^{9}$ Bolino, M.C., Turnley, W.H., dan Bloodgood, J.M. ( 2002). “Citizenship Behavior and the Creation of Social Capital in Organization". Academy of Management Journal, Vol. 7, No. 4, 2002 pp. 502 $-522$ 
2) Sportsmanship, didefinisikan kemauan atau keinginan untuk menerima (toleransi) terhadap ketidaknyamanan yang muncul dan imposition of work without complaining,

3) Organizational loyalty, merupakan bentuk perilaku loyalitas individu terhadap organisasi seperti menampilkan image positif tentang organisasi, membela organisasi dari ancaman eksternal, mendukung dan membela tujuan organisasi,

4) Organizational compliance, merupakan bentuk perilaku individu yang mematuhi segala peraturan, prosedur, dan regulasi organisasi meskipun tidak ada pihak yang mengawasi,

5) Individual initiative, merupakan bentuk self-motivation individu dalam melaksanakan tugas secara lebih baik atau melampaui standar/level yang ditetapkan. Organ menamakan dimensi ini sebagai conscientiousness dan mengatakan bahwa dimensi ini sulit dibedakan dengan kinerja in-role,

6) Civic virtue, merupakan bentuk komitmen kepada organisasi secara makro atau keseluruhan seperti menghadiri pertemuan, menyampaikan pendapat atau berpartisipasi aktif dalam kegiatan organisasi,

7) Self-development. George dan Brief mendefinisikan dimensi ini sebagai bentuk perilaku individu yang sukarela meningkatkan pengetahuan, keterampilan dan kemampuan sendiri seperti mengikuti kursus, pelatihan, seminar atau mengikuti perkembangan terbaru dari bidang yang ia kuasai ${ }^{10}$.

Sementara ada empat faktor yang mendorong munculnya Organizational Citizenship Behavior (OCB) dalam diri karyawan. Keempat faktor tersebut adalah karakteristik individual, karakteristik tugas/pekerjaan, karakteristik organisasional dan perilaku pemimpin. Karakteristik individu ini meliputi persepsi keadilan, kepuasan kerja, komitmen organisasional dan persepsi dukungan pimpinan, karakteristik tugas meliputi kejelasan atau ambiguitas peran, sementara karakteristik organisasional meliputi struktur organisasi, dan model kepemimpinan.

Menurut Organ, Organizational Citizenship Behavior (OCB) dibangun dari lima dimensi yang masing-masingnya bersifat unik, yaitu:

a. Altruism, kesediaan untuk menolong rekan kerja dalam menyelesaikan pekerjaannya dalam situasi yang tidak biasa,

${ }^{10}$ Mehboob and Bhutto. 2012. Job Satisfaction as a Predictor of Organizational Citizenship Behavior A Study of Faculty Members at Business Institutes. Jurnal Ilmu Pendidikan, Jilid 3, No 9 
94 | TAZKIR: Jurnal Penelitian Ilmu-ilmu Sosial dan Keislaman

Vol. 03 No. 1 Juni 2017

b. Civic virtue, menyangkut dukungan pekerja atas fungsi-fungsi administratif dalam organisasi,

c. Conscientiousness, menggambarkan pekerja yang melaksanakan tugas dan tanggung jawab lebih dari apa yang diharapkan,

d. Courtesy, perilaku meringankan problem-problem yang berkaitan dengan pekerjaan yang dihadapi orang lain,

e. Sportsmanship, menggambarkan pekerja yang lebih menekankan untuk memandang aspek-aspek positif dibanding aspek-aspek negative dari organisasi, sportsmanship menggambarkan sportivitas seorang pekerja terhadap organisasi.

\section{Kepuasan Kerja dengan Organizational Citizenship Behavior (OCB)}

Williams dan Anderson, menyatakan bahwa kepuasan kerja intrinsik dan ekstrinsik berpengaruh berbeda pada 2 (dua) tipe OCBs yaitu OCB-I dan OCB-O ${ }^{11}$. Konovsky dan Organ menyatakan bahwa kepuasan kerja berpengaruh pada OCB pada karyawan professional dan adminstrasi di Rumah sakit, Bolon, menemukan bahwa kepuasan kerja berpengaruh pada OCB-I dan OCB-O pada karyawan Rumah sakit Amerika bagian tenggara ${ }^{12}$. Wagner dan Rush menemukan bahwa kepuasan kerja, kepuasan gaji berpengaruh positif pada OCB pegawai yang berusia dibawah 35 tahun $^{13}$. Ackfeldt dan Coote menemukan tidak ada hubungan antara kepuasan kerja dan OCB pada karyawan retail ${ }^{14}$. Yoon dan Suh menemukan bahwa kepuasan kerja berpengaruh signifikan terhadap OCB ${ }^{15}$. Begum menyatakan bahwa kepuasan kerja yang tinggi akan berpengaruh pada OCB karyawan Bank ${ }^{16}$. Gonzales dan Garazo menemukan hubungan positif antara kepuasan kerja dan

${ }^{11}$ Williams, Lary. J \& Anderson, Stella. E. 1991. Job Satisfaction and Organizational Commitment as Predictors of Organizational Citizenship and In-Role Behavior, journal of Management, Vol. 17. No 3, 601-617

${ }^{12}$ Bolon, Douglas S, 1997. Organizational citizenship behavior among hospital employees: A multidimensional Analysis Involving Job Satisfaction and Organization Commitment, Hospital $\mathcal{E}$ Health Services Administration; Summer 1997; 42, 2; ABI/INFORM Research pg. 221

${ }^{13}$ Wagner, Sharon L \& Rush, Michael C. 2000. Altruistic organizational citizenship behavior: Context, disposition, and age The Journal of Social Psychology; Jun 2000; 140, 3; ProQuest Medical Library pg. 379

${ }^{14}$ Ackfeldt, Anna L. \& Coote, Leonard V. 2000. An Investigation Into The Antecedents Of Organizational Citizenship Behaviors ANZMAC 2000 Visionary Marketing for the 21st Century: Facing the Challenge 217

${ }^{15}$ Yoon, Mahn. Hee, Suh, Jaebeom. 2003. Organizational citizenship behaviors and service quality as external effectiveness of contact employees, Journal of Business Research 56 (2003) 597- 611

${ }^{16}$ Begum, Noorjahan 2005. The Relationships Between Social Power And Organizational Citizenship Behavior: The Meditational Role Of Procedural Justice, Organizational Commitment, And Job Satisfaction In Context Of A Private Commercial Bank In Bangladesh Independent University, Bangladesh 
OCB. Kim (2006) menemukan kepuasan kerja tidak berpengaruh pada Altruism dan Compliance $(\mathrm{OCB})^{17}$. Serta Foote dan Tang, Melakukan penelitian pada kepuasan kerja dan OCB yang dimoderasi oleh komitmen tim. Dengan menggunakan sampel sebanyak 242 pegawai yang bekerja full-time pada 3 pabrik manufaktur yang berbeda secara geografis. Penelitian ini menemukan bahwa kepuasan kerja dengan OCB berpengaruh signifikan serta komitmen tim berpengaruh pada OCB karyawan. Sedangkan hubungan antara kepuasan kerja dengan OCB di moderasi oleh komitmen tim. Dari hasil penelitian ini peneliti menyarankan untuk penelitian selanjutnya agar mengkaji konstruk tim pada situasi yang berbeda dan pada pegawai yang professional.

Dari beberapa penelitian tersebut diatas maka dapat disimpulkan bahwa masih adanya perbedaan hasil temuan antara kepuasan kerja dengan Organizational Citizenship Behavior (OCB), sehingga masih perlu diteliti kembali hubungan kedua variabel tersebut. Dari beberapa empiris terdahulu masih sangat jarang para peneliti menguji hubungan antara kepuasan kerja dengan Organizational Citizenship Behavior (OCB). Oleh karena itu dalam penelitian ini mencoba untuk menguji hubungan antara kepuasan kerja dengan Organizational Citizenship Behavior (OCB).

\section{Komitmen dan Organizational Citizenship Behavior (OCB)}

Organizational citizenship behavior $(O C B)$ adalah perilaku sukarela, perilaku melebihi tuntutan tugas, yang berkontribusi terhadap kesuksesan organisasi ${ }^{18}$. Organizational Citizenship Behavior (OCB) ditandai dengan spontanitas, dilakukan dengan sukarela, berdampak konstruktif, dan tidak mengha-rapkan pamrih ${ }^{19}$. Organizational Citizenship Behavior (OCB) menyebabkan organisasi berfungsi lebih efektif, seperti peningkatan jumlah dan kualitas produk ${ }^{20}$. Salah satu cara untuk meningkatkan perilaku OCB adalah dengan meningkatkan komit-men karyawan terhadap organisasi, khu-susnya affective commitment. Karyawan dengan affective commitment yang tinggi memiliki motivasi kerja yang lebih tinggi dan berperilaku $\mathrm{OCB}^{21}$.

\footnotetext{
${ }^{17}$ Gonza'lez, Jose' Varela \& Garazo, Teresa Garci'a. 2006. Structural relationships between organizational service orientation, contact employee job satisfaction and citizenship behavior International Journal of Service Industry Management Vol. 17 No. 1, 2006 pp. 23-50

${ }^{18}$ Sweeney, P. D., \& McFarlin, D. B. (2002). Organizational behavior: Solutions for management. NY: McGraw-Hill.

${ }^{19}$ Newstrom, J. W., \& Davis, K. (2002). Human behavior at work (11th ed.). New York: McGrawHill.

${ }^{20}$ DuBrin, A. J. (2000). Applying psychology: Individual and organizational effec-tiveness (5th ed.). NJ: Prentice Hall.

${ }^{21}$ McShane, S. L., \& Glinow, M. A. V. (2003). Organizational behavior (2nd ed.). New York: McGraw-Hill.
} 
96 | TAZKIR: Jurnal Penelitian Ilmu-ilmu Sosial dan Keislaman

Vol.03 No. 1 Juni 2017

Semakin karyawan berkomitmen (affective) terhadap organisasi, semakin karyawan bersikap melebihi tuntutan tugas apabila dibutuhkan. Hal ini membawa kar-yawan terlibat dalam berbagai bentuk $\mathrm{OCB}^{22}$.

\section{Pengajuan Hipotesis}

Berdasarkan uraian teori diatas, maka penulis merumuskan hipotesis penelitian sebagai berikut:

$\mathrm{H}_{1}$ : Terdapat pengaruh kepuasan kerja yang positif dan signifikan terhadap Organizational Citizenship Behavior (OCB) pada Pegawai Struktural IAIN Padangsidimpuan

$\mathrm{H}_{2}$ : Terdapat pengaruh komitmen pegawai yang positif dan signifikan terhadap Organizational Citizenship Behavior (OCB) pada Pegawai Struktural IAIN Padangsidimpuan.

\section{METODE PENELITIAN}

Penelitian ini dilakukan pada pegawai struktural Institut Agama Islam Negeri Padangsidimpuan. Sebagai populasi dalam penelitian ini adalah seluruh pegawai struktual Institut Agama Islam Negeri Padangsidimpuan sebanyak 53 orang dengan rincian sbb : Golongan II sebanyak 4 Orang, Golongan III sebanyak 45 orang, Golongan IV sebanyak 4 orang. Sampel adalah sebagian dari seluruh elemenelemen atau individu-individu yang terdapat pada populasi. Untuk mendapatkan data primer melalui penyebaran kuesioner yang diberikan kepada pegawai struktural mengenai kepuasan kerja, komitmen pegawai dan Organizational Citizenship Behavior (OCB). Jenis kuesioner yang digunakan adalah kuesioner terbuka yaitu responden tinggal memilih salah satu pilihan jawaban yang sudah disiapkan dengan menggunakan skala likert. Setelah proses pengumpulan datadata variabel sudah didapat, maka langkah selanjutnya melakukan pengolahan dan analisis sampai ditemukan hasilnya yang dapat dijadikan dasar pengambilan keputusan. Dalam penelitian ini menggunakan dua metode analisis, yaitu: a) Uji Reliabilitas, b) Uji Validitas, c) Uji asumsi klasik terdiri dari; uji multikoinearitas, uji heteroskedastisitas, uji normalitas. Untuk perhitungan statistik digunakan Model Analisis Regresi. Pengolahan data dalam penelitian ini dengan menggunakan program SPSS.

${ }^{22}$ Greenberg, J. (1996). Managing behavior in organizations: Science in service to practice. NY: Prentice Hall. 


\section{HASIL PENELITIAN DAN PEMBAHASAN}

\section{Uji Validitas dan Reliabilitas}

Berdasarkan hasil perhitungan melalui SPSS ver.22 dapat diperoleh hasil bahwa semua pernyataan-pernyataan yang digunakan untuk mengukur variabel independen yaitu kepuasan kerja, komitmen organisasi dan variabel dependen yaitu organizational citizenshif behavior dalam penelitian ini dinyatakan valid dan reliabel. Hal ini didasarkan bahwa nilai $r$ hitung lebih besar dari nilai $r$ tabel. Sedangkan nilai conbach alpha dari setiap variabel lebih besar dari 0,60.

\section{Analisis Regresi Berganda}

Perhitungan analisis data dalam penelitian ini adalah menggunakan bantuan program SPSS ver. 22 diperoleh persamaan regresi berganda yaitu:

$$
\mathrm{OCB}=11,266+0,870 \mathrm{KK}+0,199 \mathrm{KO}+\mathrm{e}
$$

Dari persamaan regresi diatas maka dapat diinterpretasikan beberapa hal, diantaranya:

1. Nilai konstanta dari persamaan diatas sebesar 11,266. Angka ini menunjukkan bahwa tingkat Organizational Citizenshif Behavior (OCB) bila tingkat kepuasan kerja (KK) dan komitmen organisasi (KO) diabaikan;

2. Variabel Kepuasan Kerja memiliki nilai koefisien regresi sebesar 0,870. Nilai koefisien positif menunjukkan hubungan positif Kepuasan Kerja (KK) terhadap tingkat Organizational Citizenshif Behavior (OCB). Hal ini berarti bahwa jika terjadi kenaikan Kepuasan Kerja (KK), maka nilai Organizational Citizenshif Behavior (OCB) akan mengalami peningkatan sebesar variabel pengalinya 0,870 dengan asumsi variabel independen yang lain dianggap konstan;

3. Variabel Komitmen Organisasi (KO) memiliki nilai koefisien sebesar 0,199. Hal ini juga menunjukkan hubungan positif Komitmen Organisasi (KO) terhadap Organizational Citizenshif Behavior (OCB). Dapat disimpulkan bahwa jika terjadi kenaikan Komitmen Organisasi (KO) maka nilai Organizational Citizenshif Behavior (OCB) akan mengalami peningkatan sebesar koefisien pengalinya 0,199 dengan asumsi variabel independen yang lain dianggap konstan;

4. Dari kedua nilai antara variabel Kepuasan Kerja (KK) dan Komitmen Organisasi $(\mathrm{KO})$ terdapat perbedaan dimana variabel Kepuasan Kerja (KK) berpengaruh lebih besar terhadap Organizational Citizenshif Behavior (OCB) dibanding Komitmen Organisasi (KO). 
98 | TAZKIR: Jurnal Penelitian Ilmu-ilmu Sosial dan Keislaman

Vol. 03 No. 1 Juni 2017

\section{Uji Koefisien Determinasi}

Berdasarkan hasil pengolahan data melalui SPSS dapat diketahui nilai koefisien determinasi $\mathrm{R}^{2}$ sebesar 0,830. Hasil ini menunjukkan bahwa sebesar $83 \%$ Organizational Citizenshif Behavior (OCB) pada pegawai di Institut Agama Islam Negeri Padangsidimpuan dipengaruhi oleh variasi kedua variabel independen yang digunakan yaitu kepuasan kerja dan komitmen organisasi sedangkan sisanya dipengaruhi oleh faktor lain dari penelitian ini. Dengan demikian hubungan kedua variabel bisa dikatakan cukup kuat karena $\mathrm{R}$ Square bernilai lebih dari setengan dari factor yang mempengaruhi Organizational Citizenshif Behavior (OCB).

\section{Uji Simultan/Serempak (Uji F)}

Dari hasil analisis regresi dapat diketahui bahwa secara bersama-sama variabel independen memiliki pengaruh yang signifikan terhadap variabel dependen. Hal ini dapat dibuktikan dari nilai F hitung sebesar 65.950 dengan nilai signifikansi (sig) sebesar 0,000 Karena nilai signifikansi (sig) jauh lebih kecil dari 0,05 bahwa kepuasan kerja dan komitmen organisasi secara bersama-sama berpengaruh terhadap Organizational Citizenshif Behavior (OCB). Sehingga hipotesis yang menyatakan bahwa kepuasan kerja dan komitmen organisasi secara bersamasama berpengaruh positif terhadap Organizational Citizenshif Behavior (OCB) dapat diterima.

\section{Uji Parsial (Uji t)}

Pengaruh dari masing-masing variabel Kepuasan Kerja dan Komitmen organisasi terhadap Organizational Citizenshif Behavior (OCB) dapat dilihat dari arah tanda dan tingkat signifikansi (probabilitas). Variabel Kepuasan Kerja dan Komitmen organisasi mempunyai arah yang positif,. Variabel Kepuasan Kerja berpengaruh signifikan terhadap Organizational Citizenshif Behavior (OCB) karena nilai signifikan $<0,05$, sedangkan variabel Komitmen organisasi berpengaruh tidak signifikan terhadap Organizational Citizenshif Behavior (OCB) karena nilai signifikan > 0,05.

\section{Pengaruh Kepuasan Kerja Terhadap Organizational Citizenshif Behavior (OCB)}

Hasil pengujian parsial (uji t) antara variabel Kepuasan Kerja terhadap variabel Organizational Citizenshif Behavior (OCB) menunjukkan nilai thitung sebesar 7.151 koefisien regresi sebesar 0,779 dan nilai probabilitas sebesar 0,000 yang lebih besar dari 0,05 hal ini berarti bahwa Kepuasan Kerja berpengaruh positif dan signifikan terhadap Organizational Citizenshif Behavior (OCB).

Hasil penelitian ini menunjukkan bahwa ternyata Kepuasan Kerja dengan indikator gaji, pekerjaan itu sendiri, program pengembangan SDM dan rekan kerja 
masih menjadi faktor yang signifikan terhadap Organizational Citizenshif Behavior (OCB) pada pegawai. Artinya Pegawai struktural IAIN Padangsidimpuan sebagian besar termotivasi untuk melakukan perilaku Organizational Citizenshif Behavior (OCB) karena dipengaruhi oleh kesesuaian antara gaji dengan kinerja yang telah dicapai, tantangan dalam pekerjaan, adanya jenjang karir yang jelas dan hubungan baik dengan rekan kerja. Hal ini juga didukung oleh penelitian sebelumnya oleh Yuniar, Nurtjahjanti dan Rusmawati. Penelitian ini ditujukan untuk mengetahui hubungan antara kepuasan kerja terhadap Organizational Citizenshif Behavior (OCB) pada pegawai struktural Institut Agama Islam Negeri Padangsidimpuan.

Hasil pengujian hipotesis pertama, menunjukkan bahwa kepuasan kerja berhubungan secara positif dan signifikan terhadap Organizational Citizenshif Behavior (OCB) ditunjukkan dengan koefisien korelasi 0,583 dengan tingkat signifikansi korelasi sebesar 0,000 $(\alpha<0,05)$.

\section{Pengaruh Komitmen Organisasi Terhadap Organizational Citizenshif Behavior (OCB)}

Hasil pengujian parsial (uji t) antara variabel Komitmen organisasi terhadap variabel Organizational Citizenshif Behavior (OCB) menunjukkan nilai thitung sebesar 1.641 koefisien regresi sebesar 0,179 dan nilai probabilitas sebesar 0,112 yang lebih besar dari 0,05, hal ini berarti bahwa Komitmen organisasi berpengaruh positif terhadap Organizational Citizenshif Behavior (OCB) namun tidak berpengaruh secara signifikan terhadap Organizational Citizenshif Behavior (OCB).

Dari hasil penelitian yang dilakukan ternyata Komitmen organisasi memberikan pengaruh yang positif terhadap Organizational Citizenshif Behavior $(\mathrm{OCB})$, hal ini dipengaruhi oleh indikasi bahwa karyawan yang memiliki loyalitas dan komitmen akan berusaha semaksimal mungkin untuk mencapai tujuan perusahaan dengan bertanggung jawab atas segala pekerjaan dan aktif mencari informasi-informasi penting yang berguna bagi perusahaan karena telah memiliki keterikatan emosional dengan perusahaan sehingga dengan rela dan ikhlas melakukan perilaku ekstra seperti membantu rekan kerja lain yang membutuhkan tanpa mengharapkan imbalan.

Namun komitmen diperoleh tidak signifikan disebabkan responden tidak didominasi oleh pegawai yang telah memiliki loyalitas dan komitmen organisasi yang tinggi, karena komitmen organisasi tidak dapat muncul dengan setahun atau dua tahun bekerja tetapi butuh proses dan waktu.

Dari pemaparan di atas, dapat disimpulkan bahwa variabel Kepuasan Kerja $\left(X_{1}\right)$ dan Komitmen Organisasi $\left(X_{2}\right)$ memiliki pengaruh yang positif dengan tingkat 
signifikan masing-masing terhadap variabel Organizational Citizenshif Behavior (Y), dan bahwa variabel Kepuasan Kerja memiliki pengaruh yang signifikan terhadap Organizational Citizenshif Behavior (OCB) pada pegawai. Sehingga hipotesis kedua pada penelitian ini yang menyatakan bahwa variable Kepuasan Kerja berpengaruh positif dan dominan terhadap Organizational Citizenshif Behavior (OCB) terbukti dan dapat diterima.

\section{KESIMPULAN}

Berdasarkan hasil analisis dan pembahasan, maka kesimpulan yang dapat diambil adalah Kepuasan Kerja pada pegawai Institut Agama Islam Negeri Padangsidimpuan memiliki pengaruh signifikan terhadap Organizational Citizenshif Behavior (OCB) berdasarkan persepsi pegawai. Dari hasil analisis, diperoleh hasil bahwa Kepuasan Kerja (Rekan Kerja, Gaji, Pekerjaan Itu Sendiri dan Program Pengembangan SDM) dan Komitmen Organisasi (Affective, Continuance dan Normative Commitmen) memberikan pengaruh terhadap Organizational Citizenshif Behavior (OCB) dalam lembaga. Dengan demikian, hipotesis yang diajukan dapat terbukti.

Kepuasan Kerja dan Komitmen Organisasi berpengaruh secara simultan terhadap Organizational Citizenshif Behavior (OCB). Hal ini dibuktikan dengan uji serempak (uji F) dan uji koefisien determinasi yakni sebesar 83\% Organizational Citizenshif Behavior (OCB) dipengaruhi oleh variasi kedua variabel yang digunakan dalam penelitian, sisanya adalah faktor lain. Kepuasan Kerja lebih dominan berpengaruh terhadap Organizational Citizenshif Behavior (OCB). Hal ini dibuktikan dengan koefisien regresi kepuasan kerja lebih besar dibanding komitmen organisasi berdasarkan dari penelitian yang peneliti lakukan pada lembaga Institut Agama Islam Negeri Padangsidimpuan. 


\section{DAFTAR PUSTAKA}

Ariani, D.W. Perilaku Kewargaan Organisasional. Diakses dari http://www.ugm.ac.id lindex. 2008.

Abbdurrahmat Fathoni. Organisasi dan Manajemen Sumber Daya Manusia. PT Rineka Cipta: Jakarta. 2006.

Ackfeldt, Anna L. \& Coote, Leonard V. An Investigation Into The Antecedents Of Organizational Citizenship Behaviors ANZMAC 2000 Visionary Marketing for the 21st Century: Facing the Challenge 217. 2000.

Bienstock, C.C., dkk. "Organizational Citizenship Behavior and Service Quality". Journal of Services Marketing, Vol 17 No. 4, 2003.

Begum, Noorjahan. The Relationships Between Social Power And Organizational Citizenship Behavior: The Meditational Role Of Procedural Justice, Organizational Commitment, And Job Satisfaction In Context Of A Private Commercial Bank In Bangladesh Independent University, Bangladesh. 2005.

Bolon, Douglas S, Organizational citizenship behavior among hospital employees: A multidimensional Analysis Involving Job Satisfaction and Organization Commitment, Hospital \& Health Services Administration; Summer 1997; 42, 2; ABI/INFORM Research. 1997.

Bolino, M.C., Turnley, W.H., dan Bloodgood, J.M. "Citizenship Behavior and the Creation of Social Capital in Organization". Academy of Management Journal, Vol. 7, No. 4, 2002.

DuBrin, A. J. Applying psychology: Individual and organizational effec-tiveness (5th ed.). NJ: Prentice Hall. 2000.

Donny Ubani. Pengaruh Kepemimpinan, Iklim Organisasi, dan Motivasi Kerja Terhadap Komitmen Kerja Pegawai di Dinas Koperasi Dan PK Provinsi Sumatera Barat. Tesis. Padang. UNP. 2011.

Greenberg, J. Managing behavior in organizations: Science in service to practice. NY: Prentice Hall. 1996.

Ghozali, Imam. Konsep dan Aplikasi Dengan Program AMOS 16.0, BP Undip, Semarang. 2008.

Gonza'lez, Jose' Varela \& Garazo, Teresa Garci'a. Structural relationships between organizational service orientation, contact employee job satisfaction and citizenship behavior International Journal of Service Industry Management Vol. 17 No. 1, 2006. 
102 | TAZKIR: Jurnal Penelitian Ilmu-ilmu Sosial dan Keislaman

Vol. 03 No. 1 Juni 2017

Indrawijaya. Perilaku Organisasi. Bandung: Sinar Baru. 1986.

John M. Ivancevich dkk. Perilaku dan Menajemen Organisasi. Jakarta: Erlangga. 2006.

Mehboob and Bhutto. Job Satisfaction as a Predictor of Organizational Citizenship Behavior A Study of Faculty Members at Business Institutes. Jurnal Ilmu Pendidikan, Jilid 3, No 9. 2012.

Mohammad, Habib and Alias. Job Satisfaction and Organisational Citizenship Behavior: An Empirical Study At Higher Learning Institution. Jurnal Ilmu Pendidikan, (Online), Jilid 16, No. 2. 2011.

Marwansyah. Manajemen Sumber Daya Manusia, Edisi Kedua. Bandung: Alfabeta. 2010.

McShane, S. L., \& Glinow, M. A. V. Organizational behavior (2nd ed.). New York: McGraw-Hill. 2003.

Nanggoy, S. \& Harianti, R. "Pengaruh Kepuasan Kerja Karyawan Terhadap Turnover Intentions di PT. Andalan Pacific Samudera di Surabaya" (Skripsi No.05011881/MAN/2005). Retrieved April 30, 2015. From source: http://dewey.petra.ac.id/dgt res_detail.php?knokat=2626

Nasir, Mohammadi, Shahrazad, Fatimah, Khairudin, and Halim. Relationship Between Organizational Citizenship Behavior and Task Performance. Jurnal ilmu Pendidikan, (Online), Vol 6, No 4. 2011.

Newstrom, J. W., \& Davis, K. Human behavior at work (11th ed.). New York: McGrawHill. 2002.

Organ, D.W. Organizational Citizenship Behavior: The Good Soldier Syndrome. Lexinton book. Lexington,MA. 1988.

Podsakoff, P.M., dkk. "Organizational Citizenship Behavior: a Critical Review of Theoretical Empirical Literature and Suggestions for Future Research". Journal of Management, 26 (3): 513-563, php? page=rilis\&artikel=1112. Diakses tanggal 15 Januari 2016. 2000.

Pandji Anoraga dan Sri Suyanti. Perilaku Organisasi. Jakarta: Dunia Pustaka Jaya. 1995.

Robbins dan Judge. Perilaku Organisasi. Jakarta: Salemba Empat. 2008.

Rachmawati. Manajemen Sumber Daya Manusia.Yogyakarta: C.V Andi Offset. 2008.

Sloat, K. C. M. Organizational Citizenship: Does Your Firm Inspire to be "good citizenship?". Professional Safety, Vol.44: 20-23. 1999. 
Sopiah. Perilaku Organisasional. Yogyakarta: C.V Andi Offset. 2008.

Saepung, Sukirno and Siengthai. The Study of Job Satisfaction and Organizational Citizenship Behavior (OCB) in the Retail Industry in Indonesia. Jurnal Ilmu Pendidikan, (Online), (http://www.wbiconpro.com/477-Sununtha.pdf

Susanto, Ari Juniar. Komitmen Organisasi. Education Policy Analysisarchives, (Online), diakses dari http://juniarari.blogspot.com/2011/11/komitmenorganisasi.html. 2011.

Sweeney, P. D., \& McFarlin, D. B. Organizational behavior: Solutions for management. NY: McGraw-Hill. 2002.

Sugiyono. Metode Penelitian Bisnis. Bandung: Alfabeta. 2010.

Wahyuningsih. Pengaruh Komitmen Organisasi terhadap Organizational Citizenship Behavior Karyawan Rumah Sakit PKU Muhammadiyah. Jurnal Ilmu Pendidikan, (Online). 2009.

Wahjosumidjo. Kepemimpinan dan Motivasi. Jakarta: Ghalia Indonesia. 2001.

Williams, Lary. J \& Anderson, Stella. E. Job Satisfaction and Organizational Commitment as Predictors of Organizational Citizenship and In-Role Behavior, journal of Management, Vol. 17. No 3, 601-617. 1991.

Wagner, Sharon L \& Rush, Michael C. Altruistic organizational citizenship behavior: Context, disposition, and age The Journal of Social Psychology; Jun 2000; 140, 3; ProQuest Medical Library. 2000.

Yoon, Mahn. Hee, Suh, Jaebeom. Organizational citizenship behaviors and service quality as external effectiveness of contact employees, Journal of Business Research 56 (2003). 
104 | TAZKIR: Jurnal Penelitian Ilmu-ilmu Sosial dan Keislaman

Vol. 03 No. 1 Juni 2017

\section{ANALISIS KESESUAIAN JURNAL PERKULIAHAN DOSEN DENGAN SILABUS PEMBELAJARAN TBI}

Sahadir Nasution, Rayendriani Fahmei Lubis, dan Eka Sustri Harida 